\title{
PRODUKSI TEPUNG TULANG IKAN TUNA (Thunnus $s p$ ) DENGAN METODE KERING SEBAGAI SUMBER KALSIUM DAN FOSFOR UNTUK PEMBUATAN BISKUIT
}

\author{
Suarsa, I W ${ }^{1)}$; Bawa Putra, A.A ${ }^{2)}$; Sri Rahayu Santi ${ }^{3)}$; Abdul Faruk ${ }^{4)}$ \\ ${ }^{1}$ Program Studi Kimia FMIPA Universitas Udayana; wsuarsa@yahoo.com \\ ${ }^{2}$ Program Studi Kimia FMIPA Universitas Udayana; bawa_putra@unud.ac.id \\ ${ }^{3}$ Program Studi Kimia FMIPA Universitas Udayana; sr_santi@unud.ac.id \\ ${ }^{4}$ Program Studi Kimia FMIPA Universitas Udayana; Abdulfaruk196@gmail.com
}

\begin{abstract}
ABSTRCT
Research has been conducted on processing tuna bones into flour which has a high mineral content which aims to produce nutritious biscuits in the form of food products. This study obtained the results that the tuna bone water content was $6.40 \%$ and the biscuit water content was $2.67 \%$, the calcium and phosphorus content of tuna fish was $5.35 \%$ and $3.37 \%$, while the biscuit dough with variations in the ratio between flour and fish bones namely $100: 0 ; 95: 5 ; 90: 10$; and $85: 15$ obtained the results of increased calcium content of $0.9 \% ; 0.97 \% ; 1.25 \%$; and $1.29 \%$; and phosphorus content $0.38 \% ; 0.43 \%$; $0.46 \%$; and $0.60 \%$; and the protein content is $9.32 \% ; 11.74 \%$; $11.99 \%$; and 12.4
\end{abstract}

Keywords: tuna bones; calcium; biscuits

\section{ABSTRAK}

Telah dilakukan penelitian tentang pengolahan tulang ikan tuna menjadi tepung yang memiliki kandungan mineral tinggi yang bertujuan untuk menghasilkan produk pangan berupa biskuit yang bergizi. Penelitian ini memperoleh hasil bahwa kadar air tulang ikan tuna 6,40\% dan kadar air biskuit 2,67\%, kandungan kalsium dan fosfor tulang ikan tuna adalah 5,35\% dan 3,37\%, sedangkan adonan biskuit dengan variasi perbandingan antara tepung dengan tulang ikan yakni $100: 0 ; 95: 5 ; 90: 10$; dan 85 : 15 diperoleh hasil kandungan kalsium meningkat yakni 0,9\%; 0,97\%; 1,25\%; dan 1,29\%; dan kandungan fosfor $0,38 \%$; $0,43 \%$; $0,46 \%$; dan $0,60 \%$; serta kandungan proteinnya $9,32 \% ; 11,74 \%$; $11,99 \%$; dan $12,40 \%$.

Kata Kunci : tulang ikan tuna; kalsium; biskuit

\section{PENDAHULUAN}

Pengolahan ikan belum optimal dilakukan sampai dengan pengolahan limbah hasil perikanan seperti kepala, tulang, sisik, dan kulit ikan. Seiring dengan berkembangnya industri perikanan, limbah yang dihasilkan juga meningkat dan pemanfaatan dari limbah tulang ikan tersebut belum maksimal. Proses pengolahan ikan hampir selalu menghasilkan limbah padatan yang memberikan dampak tidak baik pada lingkungan karena menimbulkan pencemaran. Limbah padat yang dihasilkan dari industri pengolahan ikan maupun kegiatan rumah tangga cukup besar, salah satunya ialah tulang ikan. Limbah perikanan yang berasal dari tulang ikan tuna sebagai salah satu contoh limbah yang belum diolah dan dimanfaatkan secara maksimal (Widya dan Parlin, 2016). 
Salah satu bentuk pengolahan tulang ikan tuna yang dilakukan adalah dengan cara mengolah menjadi tepung (Laode, dkk, 2018). Tepung tulang ikan adalah suatu produk padat kering yang dihasilkan dengan cara mengeluarkan sebagian besar cairan atau seluruhnya lemak yang terkandung pada tulang ikan (Bone, dkk, 2006). Aplikasi pemanfaatan tepung tulang ikan dalam bentuk produk pangan telah dilakukan oleh beberapa peneliti diantaranya diteliti oleh Agung, dkk (2019) dengan penelitiannya pemanfaatan limbah tulang ikan tuna dalam pembuatan cilok sebagai sumber kalsium.

Tepung tulang ikan tuna dengan kandungan kalsium dan fosfor yang tinggi dapat merupakan sumber alternatif pemenuhan kebutuhan akan kalsium dan fosfor bagi tubuh. Pemanfaatan tepung tulang ikan tuna dalam bahan pangan sangatlah dimungkinkan (Didi, dkk, 2013). Solubilitas tepung tulang ikan tuna sangat mutlak diketahui baik dalam bentuk tepung maupun yang telah ditambahkan ke dalam bahan pangan (Wini, dkk, 2006). Hal ini dikarenakan seberapa besarpun kandungan kalsium dan fosfor yang dimiliki oleh bahan pangan tetapi tidak dicerna sempurna oleh tubuh maka tidak akan memiliki efek yang banyak (Haqqy, dkk, 2017).

Kalsium pada ikan terutama pada tulang membentuk kompleks dengan fosfor dalam bentuk apatit atau trifosfat dan bentuk kompleks ini terdapat pada tepung tulang yang dapat diserap dengan baik oleh tubuh (Ruslan, 2019). Kalsium dibutuhkan untuk proses pembentukan dan perawatan jaringan rangka tubuh serta beberapa kegiatan penting dalam tubuh seperti membantu dalam pengaturan transport ionion lainnya ke dalam maupun ke luar membran, berperan dalam penerimaan dan interpretasi pada impuls saraf, pembekuan darah dan pemompaan darah, kontraksi otot, menjaga keseimbangan hormon, dan katalisator pada reaksi biologis (Intan, dkk, 2019).

Tulang ikan tuna yang telah menjadi tepung memiliki kandungan mineral tinggi terutama kalsium dan fosfor (Ruslan, 2019), untuk itu pengolahan tulang ikan menjadi tepung diterapkan menjadi suatu produk pangan yang mudah diterima oleh kalangan masyarakat. Pemilihan bentuk produk pangan yang dipilih ialah biskuit dengan pertimbangan produk ini telah banyak dikenal dan cocok untuk semua golongan usia serta harga yang ekonomis. Oleh karena itu maka dikerjakan penelitian mengenai sifat fisikokimia, kandungan kalsium dan fosfor pada produk biskuit yang dihasilkan dari tepung tulang ikan tuna.

\section{METODE PENELITIAN}

\section{Bahan dan Alat Penelitian}

a. Bahan penelitian

Bahan yang digunakan dalam penelitian ini yaitu tulang ikan tuna, tepung 
terigu, margarin, susu, backing powder, telur, air, gula, garam, vanili, $\mathrm{H}_{2} \mathrm{SO}_{4}$, $\mathrm{FeSO}_{4} .7 \mathrm{H}_{2} \mathrm{O}, \mathrm{H}_{3} \mathrm{BO}_{3}$, ammonium molibdat, indikator metil merah, indikator metil biru, kertas saring whattman, $\mathrm{NaOH}, \mathrm{HCl}$, $\mathrm{HNO}_{3}, \mathrm{HClO}_{4}$, akuades, tablet kjeltab, $\mathrm{KH}_{2} \mathrm{PO}_{4}$, standar $\mathrm{CaCl}_{2}$.

\section{b. Alat yang digunakan}

Alat-alat yang digunakan dalam penelitian ini adalah pengering drum, oven, ayakan ukuran 100 mesh, cetakan, timbangan, mixer, neraca analitik, peralatan gelas, labu Kjeldhal, penangas air, Atomic Absorption Spectrophotometer (AAS), Spektrofotometer UV-vis, cawan porselin, kertas saring, sentrifuse.

\section{Tempat Penelitian}

Penelitian ini dilakukan di Laboratorium Penelitian Program studi Kimia Fakultas MIPA Universitas Udayana. Analisis kadar kalsium dengan AAS dan analisis kadar fosfor dengan spektrofotometer ulrta violet-visibel dilakukan di Laboratorium Penelitian Terpadu Fakultas MIPA Universitas Udayana.

\section{Pembuatan Tepung Tulang Ikan dengan Metode Kering}

Sampel tulang ikan tuna dicuci dengan air untuk menghilangkan pengotor, kemudian direbus selama 2 jam. Tulang ikan tuna yang telah direbus kemudian dicuci lalu dicincang sehingga ukurannya menjadi kecil-kecil. Pembuatan tepung tulang ikan dilakukan dengan metode kering yaitu tulang ikan dikeringkan dalam oven pada suhu $105^{\circ} \mathrm{C}$ selama 1,5 jam. Tulang ikan yang telah kering kemudian digiling sampai halus dan diayak dengan ayakan ukuran 100 mesh.

\section{Pembuatan Biskuit}

\section{a. Pembuatan biskuit $0 \%$}

Bahan-bahan seperti $100 \mathrm{~g}$ tepung terigu, 0,25 sendok teh soda kue, 0,25 sendok teh garam, 1 butir telur, 1 pak vanili, 0,25 sendok teh gula, 2 sendok makan mentega, dan $25 \mathrm{~mL}$ susu dicampur dan di mixer untuk mehomogenkan, dicetak dengan cetakan lalu dioven pada suhu $110^{\circ} \mathrm{C}$ selama kurang lebih 30 menit.

\section{b. Pembuatan biskuit 5\%}

Bahan-bahan seperti $100 \mathrm{~g}$ tepung terigu, 0,25 sendok teh soda kue, 0,25 sendok teh garam, 1 butir telur, 1 pak vanili, 0,25 sendok teh gula, 2 sendok makan mentega, $25 \mathrm{~mL}$ susu dan 5 gram tepung tulang ikan, dicampur dan di mixer untuk mehomogenkan, dicetak dengan cetakan lalu dioven pada suhu $110^{\circ} \mathrm{C}$ selama kurang lebih 30 menit.

\section{c. Pembuatan biskuit $10 \%$}

Cara pembuatan biskut $10 \%$ sama dengan sebelumnya hanya saja berbeda pada jumlah tepung tulang ikan yang digunakan yaitu 10 gram.

\section{d. Pembuatan biskuit $\mathbf{1 5 \%}$}

Cara pembuatan biskut 15\% sama dengan sebelumnya hanya saja berbeda pada jumlah tepung tulang ikan yang digunakan yaitu 15 gram. 


\section{Karakterisasi Tepung Tulang Ikan dan Biskuit}

\section{a. Kadar air}

Cawan kosong dikeringka pada suhu $100-102^{\circ} \mathrm{C}$ selama 15 menit, kemudian didinginkan dalam desikator dan ditimbang. Sebanyak 5 g sampel (W1) dimasukkan ke dalam cawan yang telah dikeringkan dalam oven dan ditimbang (W2), kemudian dikeringkan dalam oven pada suhu $100-102^{\circ}$ Cselama 6 jam. Cawan tersebut kemudian dimasukkan didesikator dan ditimbang hingga berat konstan (W3).

Kadar air dihitung dengan rumus :

Kadar Air $=\frac{W 2-w 3}{w 1} \times 100 \%$

Keterangan :

W1 menyatakan berat sampel (g), W2 menyatakan berat cawan + sampel minyak sebelum dipanaskan (g) dan W3 menyatakan berat cawan + sampel minyak setelah dipanaskan $(\mathrm{g})$.

\section{b. Kadar kalsium}

$\underline{\text { Pembuatan larutan standar }}$

Larutan standar kalsium dibuat dengan menimbang beberapa gram $\mathrm{CaCl}_{2}$ kemudian diencerkan ke dalam labu ukur $100 \mathrm{~mL}$ dengan larutan asam nitrat sampai tanda batas.

$\underline{\text { Penetapan sampel }}$

Pengabuan basah menggunakan $\mathrm{HNO}_{3} 65 \%, \mathrm{H}_{2} \mathrm{SO}_{4} 96-98 \%, \mathrm{HClO}_{4} 60 \%$ dan $\mathrm{HCl}$ 37\%. Sebanyak $1 \mathrm{~g}$ sampel dimasukkan ke dalam erlenmeyer $150 \mathrm{~mL}$ dan ditambahkan $\mathrm{HNO}_{3} 5 \mathrm{~mL}$, kemudian didiamkan selama 1 jam. Sampel selanjutnya dipanaskan selama 4 jam di atas hot plate, kemudian didinginkan. Setelah itu ditambahkan $\mathrm{H}_{2} \mathrm{SO}_{4}$ sebanyak 0,4 mL dan dipanaskan kembali selama 30 menit. Sampel diangkat dari hot plate dan diberi larutan $\mathrm{HClO}_{4}: \mathrm{HNO}_{3}$ (2:1) sebanyak $3 \mathrm{~mL}$, kemudian dipanaskan selama 15 menit hingga sampel menjadi bening. Sampel ditambahkan $2 \mathrm{~mL}$ akuades dan 0,6 $\mathrm{mL} \mathrm{HCl}$, setelah bening dipanaskan hingga larut lalu didinginkan. Sampel diencerkan sampai volume tertentu (aliquot $100 \mathrm{~mL}$ ), kemudian disaring menggunakan kertas saring Whatman No. 42. Aliquot diambil sebanyak $1 \mathrm{~mL}$, dimasukkan ke dalam tabung reaksi dan ditambahkan akuades $4 \mathrm{~mL}$ serta lantan $0,05 \mathrm{~mL}$ selanjutnya divortex, disentrifuse dengan kecepatan 2000 rpm selama 10 menit dan filtrat dianalisis dengan AAS pada panjang gelombang 422,7 nm. Hasil absorbansinya dibandingkan dengan standar kalsium yang telah diketahui. Untuk menentukan kadar kalsium digunakan persamaan sebgai berikut;

$C a=\frac{\left(m L \frac{\text { aliquot }}{1000}\right) \times F P \times(\text { ppm sampel }- \text { ppm blanko })}{m g \text { sampel }} \times 100 \%$

$\mathrm{FP}=$ faktor pengenceran

$\mathrm{Ca}(\mathrm{mg} / 1000)=\% \mathrm{Ca} \times 1000$

\section{c. Kadar fosfor}

$\underline{\text { Preparasi larutan }}$

Sebanyak $10 \quad \mathrm{~g}$ ammonium molibdat diencerkan dengan $60 \mathrm{~mL}$ akuades dalam labu takar, kemudian ditambahkan $28 \mathrm{~mL} \mathrm{H}_{2} \mathrm{SO}_{4}$ pekat secara 
bertahap dan diencerkan dalam akuades hingga $100 \mathrm{~mL}$ untuk menghasilkan larutan ammonium molibdat 10\% (Larutan A). Sebelum dianalisis, larutan A diambil sebanyak $10 \mathrm{~mL}$ dan ditambahkan dengan $60 \mathrm{~mL}$ akuades dan 5 g $\mathrm{FeSO}_{4} \cdot 7 \mathrm{H}_{2} \mathrm{O}$ ke dalam labu takar $100 \mathrm{~mL}$ dan diencerkan untuk menghasilkan larutan B.

\section{Pembuatan larutan standar}

$\begin{array}{llll}\text { Sebanyak } & 4,394 & \mathrm{~g} & \mathrm{KH}_{2} \mathrm{PO}_{4}\end{array}$ dilarutkan dalam akuades sampai 1000 mL untuk mendapatkan fosfor dengan konsentrasi 1000 ppm. Sebanyak $10 \mathrm{~mL}$ larutan tersebut kemudian diencerkan dengan penambahan akuades $400 \mathrm{~mL}$ sehingga didapatkan konsentrasi 25 ppm. Kemudian dibuat konsentrasi larutan standar fosfor $0,1,2,4$, dan 8 ppm dalam labu ukur $50 \mathrm{~mL}$, ditambahkan $2 \mathrm{~mL}$ larutan B dan akuades hingga $5 \mathrm{~mL}$, kemudian dibaca dalam spektrofotometer UV-vis dengan panjang gelombang 680 $\mathrm{nm}$.

\section{Preparasi sampel}

Sampel ditimbang 10,0 gram ke dalam cawan porselen, lalu sampel ditanur atau proses pengabuan sampai bebas karbon selama 3 jam pada suhu $600^{\circ} \mathrm{C}$ kemudian didinginkan. Sampel yang telah ditanur dimasukkan ke dalam gelas beaker $250 \mathrm{~mL}$ kemudian ditambahkan $40 \mathrm{~mL}$ $(1: 3 \mathrm{HCl}$ : aquades) dan beberapa tetes $\mathrm{HNO}_{3}$ dipanaskan dalam water batch dan didinginkan lalu ditambahkan sampai tanda batas dengan akuades.
Larutan sampel ditambahkan $2 \mathrm{~mL}$ larutan B, kemudian dipipet ke dalam kuvet sebanyak $3 \mathrm{~mL}$ dan dibaca pada panjang gelombang $680 \mathrm{~nm}$. Nilai absorbansi larutan standar 0, 1, 2, 4, dan 8 ppm diukur dan diregresikan sehingga didapat $\mathrm{y}=\mathrm{a}+$ bx. Nilai absorbansi sampel (y) dimasukkan untuk mendapatkan nilai konsentrasi (x).

\section{d. Kadar protein}

Ditimbang dengan teliti $1 \mathrm{~g}$ sampel biskuit, kemudian dimasukkan ke dalam labu Kjeldhal dan ditambahkan $10 \mathrm{~g}$ campuran selen (Kjeltab) serta $30 \mathrm{~mL}$ $\mathrm{H}_{2} \mathrm{SO}_{4}$ pekat. Setelah itu dipanaskan di ruang asam hingga warna cairan menjadi hijau jernih dan didinginkan. Sampel diencerkan dengan 250-300 $\mathrm{mL}$ akuades dan dipindahkan ke tabung destilasi yang telah diberi batu didih. Setelah itu ditambahkan dengan $12 \mathrm{~mL} \mathrm{NaOH} 30 \%$ dan segera disambung dengan alat destilasi dan didestilasi hingga $2 / 3$ dari cairan tersebut menjadi destilat. Hasil destilasi ditampung dengan gelas erlenmeyer 125 mL yang telah berisi $10 \mathrm{~mL}$ larutan $\mathrm{H}_{3} \mathrm{BO}_{3}$ dan 2-3 tetes indikator campuran metil merah dan metil biru. Hasil dari destilasi ini dititrasi dengan larutan $\mathrm{HCl} 0.1 \mathrm{~N}$.

\section{HASIL DAN PEMBAHASAN}

\section{Pembuatan Tepung Tulang Ikan Tuna}

Tulang ikan tuna dicuci dengan air kemudian direbus selama 2 jam selanjutnya dicuci dan dipotong-potong hingga ukuran terkecil lalu dikeringkan 
dalam oven pada suhu $105^{\circ} \mathrm{C}$ selama 1,5 jam. Tulang ikan yang telah kering kemudian digiling sampai halus dan diayak dengan ayakan ukuran 100 mesh dimana tepung tulang ikan tuna yang diperoleh sebagaimana pada Gambar 1.

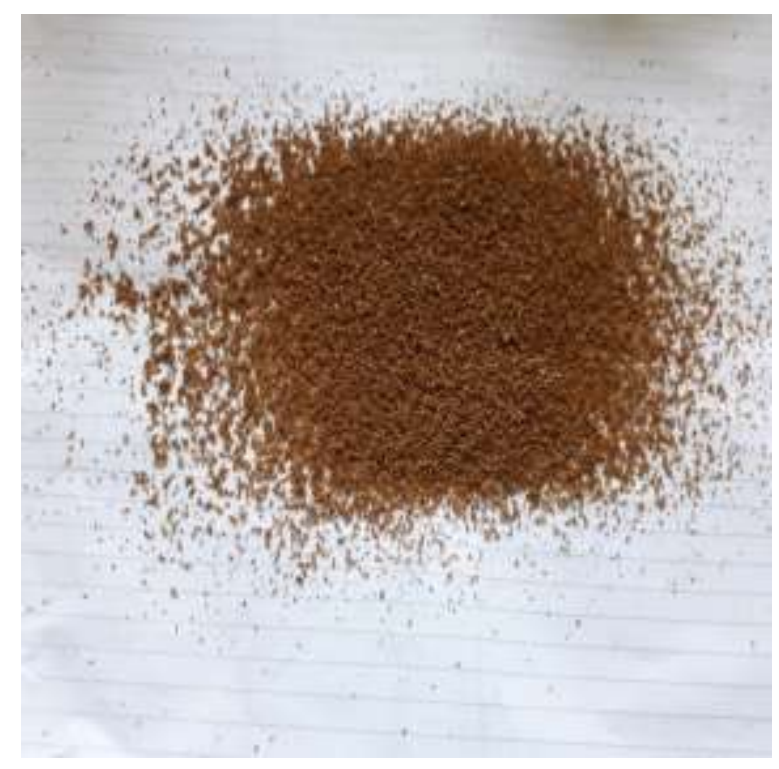

Gambar 1. Tepung Tulang Ikan Tuna

Kandungan tepung tulang ikan dikenal sebagai unsur mineral. Mineral tersebut merupakan salah satu komponen dalam bahan makanan. Komponen ini terdiri dari kalium, fosfor, natrium, magnesium, kalsium, besi, mangan, dan tembaga (Imra, dkk, 2019). Kadar mineral dalam bahan pangan mempengaruhi sifat fisik bahan pangan serta keberadaannya dalam jumlah tertentu mampu menghambat pertumbuhan mikro organisme jenis tertentu (Widya dan Parlin, 2016).

\section{Kadar Air}

Pengukuran kadar air sampel dilakukan proses pengeringan sampel dalam oven pada suhu $100-102^{\circ} \mathrm{C}$ selama 6 jam sampai diperoleh berat konstan. Hasil pengukuran kadar air tulang ikan tuna diperoleh sebesar $6,40 \%$, sedangkan ratarata kadar air biskuit adalah 2,67\%.

Kualitas bahan makanan berhubungan dengan kadar air dari bahan makanan tersebut. Selain kadar air, kualitas bahan makanan juga dipengaruhi oleh temperatur, adanya oksigen, jamur, insekta, dan lamanya penyimpanan. Proses pengeringan didasarkan pada terjadinya penguapan air. Prinsip pengeringan adalah mengurangi kandungan air pada produk makanan (Kusumaningrum dan Asikin, 2016).

Reaksi kimia yang terjadi selama proses pemanasan saat pengeringan tepung tulang ikan adalah oksidasi lemak yang menghasilkan senyawa-senyawa antara lain aldehida dan keton yang bisa bereaksi antara satu dengan yang lain membentuk polimer lipid. Proses oksidasi dapat berlangsung bila terjadi kontak antara sejumlah oksigen dengan lemak dan biasanya dimulai dengan pembentukan peroksida dan hidroperoksida. Tingkat selanjutnya adalah terurainya asam-asam lemak disertai dengan konversi hidroperoksida menjadi keton serta asamasam lemak bebas (Intan, dkk, 2019).

\section{Kadar Kalsium}

Penentuan kadar kalsium yang terkandung dalam tulang ikan tuna dan biskuit dikerjakan dengan menggunakan metode spektrometri serapan atom dan 
diawali dengan pembuatan kurva baku kalsium dan dilanjutkan pengukuran sampel. Berdasarkan data pengukuran dengan Spektrometer Serapan Atom diperoleh persamaan kurva baku kalsium adalah $\mathrm{y}=0,100 . \mathrm{x}+0,009$ dengan harga $\mathrm{R}^{2}=0,994$. Hasil pengukuran sampel tulang ikan diperoleh data bahwa kandungan kalsium tepung tulang ikan tuna sebesar 5,35\%. Sedangkan hasil pengukuran sampel biskuit diperoleh data bahwa kandungan kalsiumnya berdasarkan variasi perbandingan antara tepung terigu dengan tepung tulang ikan tuna dipaparkan sebagaimana tertera dalam Tabel 1:

Tabel 1. Kadar Kalsium Pada Biskuit.

\begin{tabular}{|c|c|}
\hline $\begin{array}{c}\text { Sampel Adonan Biskuit } \\
\text { (Tepung : Tulang Ikan) }\end{array}$ & $\begin{array}{c}\text { Kadar Kalsium } \\
(\%)\end{array}$ \\
\hline $100: 0$ & 0,92 \\
$95: 5$ & 0,97 \\
$90: 10$ & 1,25 \\
$85: 15$ & 1,29 \\
\hline
\end{tabular}

Tubuh mengandung kalsium (Tabel 1) yang lebih banyak dibandingkan mineral lain (Dio, dkk, 2018). Peranan kalsium di dalam tubuh dapat dibagi dua, yakni membantu membentuk tulang dan gigi dan mengatur proses biologis di dalam tubuh (Nurul dan Evi, 2019). Keperluan kalsium terbesar adalah ketika masa pertumbuhan dan keperluan terhadap asupan kalsium masih diteruskan, meskipun sudah mencapai usia dewasa (Fauzi, dkk, 2018).

Kadar kalsium dalam biskuit pada formulasi 100:0 dikarenakan komposisi tepung terigu yang mendominasi yaitu sebanyak 100 gram tepung terigu tanpa ada tambahan tulang ikan tuna, sehingga sumber kalsium hanya berasal dari tepung terigu. Sedangkan komposis pada formulasi 95:5, sebanyak 95 gram tepung terigu dan 5 gram tepung tulang ikan tuna mengandung kalsium sebanyak 0,97\%, formulasi 90:10, 90 gram tepung terigu dan 10 gram tepung tulang ikan tuna menunjukan bahwa kadar kalsiumnya sebesark 1,25\%, sedangkan formulasi $85: 15$, sebanyak 85 gram tepung terigu dan 15 gram tulang ikan tuna terdeteksi kadar kalsium sebesar 1,29\%. Kenaikan kandungan kadar kalsium dikarenakan sumber kalsium didapatkan dari bahan baku tersebut yaitu tepung tulang ikan tuna.

Kalsium terdapat dalam berbagai bentuk diantaranya adalah kalsium fosfat, kalsium sitrat, dan kalsium asetat. Pada ikan, kalsium terdapat pada jaringan tubuh, kerangka, dan sirip (Indrati, dkk, 2016). Perbedaan kandungan kalsium pada tepung tulang ikan, dipengaruhi oleh perbedaan jenis ikan yang digunakan. Kandungan mineral pada ikan bergantung pada spesies, jenis kelamin, siklus biologis, dan bagian tubuh yang dianalisis (Wini, dkk, 2006). Faktor ekologis seperti musim, tempat pembesaran, jumlah nutrisi tersedia, suhu, dan salinitas air juga dapat mempengaruhi kandungan mineral dalam tubuh ikan (Kusumaningrum dan Asikin, 2016). 


\section{Kadar Fosfor}

Penentuan kadar fosfor yang terkandung dalam sampel dikerjakan dengan menggunakan metode spektrometri ultra violet - visibel dan diawali dengan pembuatan kurva baku fosfor dan dilanjutkan pengukuran sampel.

Berdasarkan data pengukuran dengan Spektrometer Ultra Violet - Visible diperoleh persamaan kurva baku fosfor adalah $y=0.102 x+0.008$ dengan harga $R^{2}$ $=0,999$. Hasil pengukuran sampel tepung tulang ikan diperoleh kandungan fosfor sebesar 6,21\%. Sedangkan hasil pengukuran sampel biskuit diperoleh data kandungan fosfornya sebagaimana tertera pada Tabel 2:

Tabel 2. Data Hasil Analisis Fosfor Pada Biskuit.

\begin{tabular}{|c|c|}
\hline $\begin{array}{c}\text { Sampel Adonan Biskuit } \\
\text { (Tepung : Tulang Ikan) }\end{array}$ & $\begin{array}{c}\text { Kadar Posfor } \\
(\%)\end{array}$ \\
\hline $100: 0$ & 0,38 \\
$95: 5$ & 0,43 \\
$90: 10$ & 0,46 \\
$85: 15$ & 0,60 \\
\hline
\end{tabular}

Berdasarkan Tabel 2 menunjukkan bahwa semakin banyak ditambahkan tepung tulang ikan tuna maka semakin naik kadar fosfor pada adonan biskuit yang dihasilkan. Fosfor merupakan salah satu unsur utama pembentuk tulang ikan, dimana ketersediaan fosfor dalam bahan pangan dapat mempengaruhi kandungan kalsium sehinga kandungan fosfor berkaitan dengan ketersediaan kalsium (Ruslan, 2019).
Fosfor, sebagaimana mineral yang lain bersifat stabil terhadap proses perebusan, karena unsur mineral relatif stabil dengan adanya proses perebusan. Nilai kadar fosfor yang dihasilkan sejalan dengan besarnya kadar kalsium tepung tulang ikan. Proses absorbsi kalsium yang baik memerlukan perbandingan kalsium dengan fosfor dalam rongga usus yang tepat, bila perbandingan antara kalsium dengan fosfor tidak seimbang akan menghambat penyerapan kalsium (Imra, dkk, 2019).

\section{Kadar Protein Biskuit}

Penentuan kadar protein yang terkandung dalam biskuit dikerjakan dengan menggunakan metode volumetri dan diawali dengan pembuatan larutan baku primer dan larutan baku sekunder dan dilanjutkan titrasi sampel biskuit. Berdasarkan data titrimetri diperoleh data kandungan protein biskuit dengan variasi antara tepung dengan tulang ikan tuna dipaparkan dalam Tabel 3:

Tabel 3. Kadar Protein Pada Biskuit.

\begin{tabular}{|c|c|}
\hline $\begin{array}{c}\text { Sampel Adonan Biskuit } \\
\text { (Tepung : Tulang Ikan) }\end{array}$ & $\begin{array}{c}\text { Kadar Protein } \\
(\%)\end{array}$ \\
\hline $100: 0$ & 9,32 \\
$95: 5$ & 11,74 \\
$90: 10$ & 11,99 \\
$85: 15$ & 12,40 \\
\hline
\end{tabular}

Berdasarkan Tabel 3 menunjukkan bahwa semakin tinggi penambahan tepung tulang ikan tuna maka kadar protein pada biskuit semakin meningkat. Ini 
menunjukkan bahwa kwalitas biskuit yang dihasilkan semakin baik dimana protein merupakan sumber energi yang dibutuhkan tubuh untuk pertumbuhan dan perkembangan (Haqqy, dkk, 2017).

Protein merupakan senyawa organik yang mengandung atom karbon, hidrogen, oksigen, dan nitrogen yang disimpan dalam otot, tulang, darah, dan kulit. Protein ini akan dipecah menjadi sumber energi dan pertumbuhan jaringan (Wini, dkk, 2006). Pertumbuhan dan pemeliharaan jaringan dimungkinkan bila tersedia susunan asam amino tertentu yang sesuai (Kusumaningrum dan Asikin, 2016).

\section{SIMPULAN DAN SARAN SIMPULAN}

Kadar air tulang ikan tuna sebesar $6,40 \%$ dan kadar air biscuit 2,67\%, dan kandungan kalsium dan posfor tulang ikan tuna adalah $5,35 \%$ dan $3,37 \%$, dan adonan biskuit dengan variasi perbandingan antara tepung dengan tulang ikan yakni 100 : 0, $95: 5,90: 10$, dan $85: 15$ diperoleh hasil kandungan kalsium meningkat yakni 0,9; 0,97; 1,25; dan 1,29; dan kandungan posfor 0,$38 ; 0,43 ; 0,46$; dan 0,60; serta kandungan proteinnya 9,$32 ; 11,74 ; 11,99$; dan 12,40 .

\section{SARAN}

Setelah diperoleh kondisi-kondisi ini, perlu dilanjutkan untuk analisis kualitas tepung ikan tuna yang dihasilkan.

\section{UCAPAN TERIMAKASIH}

Pada kesempatan ini, peneliti mengucapkan terimakasih kepada Rektor Universitas Udayana atas biaya penelitian yang disetujui dengan skim DIPA BLU Universitas Udayana tahun Anggaran 2019 sesuai dengan Surat Perjanjian Penugasan Pelaksanaan Penelitian Unggulan Program Studi Nomor : 2016/UN14.2.8.II/LT/2019, tanggal 10 April 2019.

\section{DAFTAR PUSTAKA}

Agung Hermawan Susanto, Rosyid Ridho, dan Sulistiono, 2019, Pemanfaatan Limbah Tulang Ikan Tuna Dalam Pembuatan Cilok Sebagai Sumber Kalsium, Lemuru, 1 (1), 25-33;

Bone Powder, Ratih Septianingsih, Rafitah Hasanah, dan Indrati Kusumaningrum, 2006, Pengaruh Lama Proses Presto Terhadap Karakteristik Tepung Tulang Ikan Belida (Chitala sp.), J. Aquawarman. 2 (1), 34-42;

Didi Indrawan Bunta, Asri Silvana Naiu, dan Nikmawati Susanti Yusuf, 2013, Pengaruh Penambahan Tepung Tulang Ikan Tuna terhadap Karakteristik Hedonik Kue Bagea Khas Gorontalo, Jurnal Ilmiah Perikanan dan Kelautan, 1 (2) : 8188 ;

Dio Rachman Syah, Sumardianto, dan Laras Rianingsih, 2018, Pengaruh Penambahan Tepung Kalsium Tulang Ikan Bandeng (Chanos chanos) Terhadap Karakteristik Kerupuk Rambak Tapioka, J. Peng. \& Biotek. Hasil Pi, 7 (1) : 25-33;

Fauzi Rachmansyah, Evi Liviawaty, Achmad Rizal, dan Nia Kurniawati, 2018, Fortifikasi Tepung Tulang Cakalang Sebagai Sumber Kalsium 
Terhadap Tingkat Kesukaan Kerupuk Gendar, Jurnal Perikanan dan Kelautan, IX (1) : 62-70;

Haqqy Sahri Syadeto, Sumardianto, dan Lukita Purnamayati, 2017, Fortifikasi Tepung Tulang Ikan Nila (Oreochromis niloticus) Sebagai Sumber Kalsium dan Fosfor Serta Mutu Cookies, Jurnal Ilmiah Teknosains, 3 (1) : 17-21;

Imra, Mohammad Fadnan Akhmadi, Ira Maya Abdiani, dan Heni Irawati, 2019, Karakteristik Tepung Tulang Ikan Bandeng (Chanos chanos) Dari Limbah Industri Baduri Kota Tarakan, Jurnal TECHNO-FISH, III (2) : 60-69;

Indrati Kusumaningrum, Doddy Sutono, dan Bagus Fajar Pamungkas, 2016, Pemanfaatan Tulang Ikan Belida Sebagai Tepung Sumber Kalsium Dengan Metode Alkali, JPHPI, 19 (2), 148-155;

Intan Nurzahra Kaswanto, Desmelati, Dewita, dan Andarini Diharmi, 2019, Karakteristik Fisiko-Kimia dan Sensori Kerupuk Pangsit dengan Penambahan Tepung Tulang Nila (Oreochromis niloticus), Jurnal Agroindustri Halal, 5 (2) : 141-150;

Kusumaningrum I. dan Asikin AN, 2016, Karakteristik kerupuk ikan fortifikasi dari tulang ikan belida (Chitala sp.), Jurnal Pengolahan Hasil Perikanan Indonesia, 19 (3) : 233-240;
Laode Marsan, Abdurahman Baco, Nur Asyik, 2018, Penilaian Organoleptik dan Nilai Gizi Kue Karasi Yang Diperkaya Tepung Tulang Ikan Tuna (Thunnus albacor), J. Sains dan Teknologi Pangan, 3 (1) , 10831092;

Nurul Chintya Deswita dan Evi Fitriyani, 2019, Kadar Kalsium dan Mutu Edonik Donat Yang Ditambahkan Tepung Kalsium Tulang Ikan Tongkol (Euthynnus affinis), Octopus, 8 (1) : 13-19;

Ruslan A. Daeng, 2019, Pemanfaatan Tepung Tulang Ikan Cakalang (Katsuwonuspelamis) sebagai Sumber Kalsium dan Fosfor untuk Meningkatkan Nilai Gizi Biskuit, Jurnal BIOSAINSTEK. 1 (1) : 22 30 ;

Widya Ayu Lestari dan Parlin Dwiyana, 2016, Pemanfaatan Limbah Tulang Ikan Tuna (Thunnus sp) Dalam Bentuk Tepung Pada Pembuatan Stick, Jurnal Ilmu Kesehatan, 8 (2) : 46-53;

Wini Trilaksani, Ella Salamah, dan Muhammad Nabil, 2006, Pemanfaatan Limbah Tulang Ikan Tuna (Thunnus sp.) Sebagai Sumber Kalsium Dengan Metode Hidrolisis Protein, Buletin Teknologi Hasil Perikanan, IX (2), 34-45. 